Technical Paper

\title{
Evaluation of Cellulase Activity in Enzymatic Hydrolysis Residues for Efficient Enzyme Reuse
}

\author{
Fumio HaSEGAWA ${ }^{*}{ }^{\dagger}$, Hiroyuki InOUE ${ }^{* 2}$, Shinichi YANO ${ }^{* 2}$, Shinya YOKOYAMA ${ }^{* 3}$, and Kenji IMOU ${ }^{* 1}$ \\ (Received April 20, 2016)
}

\begin{abstract}
Enzymatic hydrolysis by cellulase has potential as an environment-friendly technology for producing bioethanol from lignocelluloses, but its production cost remains expensive. Therefore, several studies have examined methods in reducing the cost of enzymatic hydrolysis, and one of the most effective ways is to reuse enzymes. In this study, we developed a method for evaluating the cellulase activity in enzymatic hydrolysis residues for efficient enzyme reuse. Approximately $70 \%$ the of cellulase activity remained in the solid residue after $70 \%$ of the glucan was hydrolyzed, and $22 \%$ of cellulase activity still remained in the solid residue after $99 \%$ of glucan was hydrolyzed. Other experiments were performed in order to examine the application of our proposed method for practical reuse of enzymes. The results indicate that enzymes were recovered from the residues as we estimated by our method. Thus our method is efficient for evaluating cellulase activity in enzymatic hydrolysis residues.

セルラーゼによる酵素糖化は，環境負荷の少ないセルロースの糖化方法として期待されているが，そのコストの高さが課題となっ ている。そのため, 酵素糖化のコスト削減に向けた研究が数多〈行われ, 酵素のリサイクルは酵素糖化のコストを削減する有効な方 法の一つと考えられている。本研究では, 酵素糖化後の固体残椬に残る酵素の効率的なリサイクルを目指し, 酵素糖化後の固体残 椬に残存する酵素活性を測定する方法を提案する。本研究で提案した方法で固体残椬に残る酵素活性を測定した結果, 糖化率 70\%の固体残椬には添加した酵素の 70\%の活性が, 糖化率 99\%の残椬には 22\%の活性が残っていることが明らかとなった。また, 酵素のリサイクルを想定した酵素糖化試験を行い, 本研究で測定した結果からの予測通りに固体残椬から酵素が回収できることが 確認された。
\end{abstract}

\section{Key Words}

Enzyme reuse, Bioethanol, Cellulase, Enzymatic hydrolysis

\section{Introduction}

Recently bioethanol production from lignocellulosic biomass has been developed all over the world. Enzymatic hydrolysis by cellulase has attracted considerable attention because of its potential as an environment-friendly technology for producing bioethanol from lignocelluloses, but production cost of cellulase remains expensive. Therefore,

※ 1 Graduate School of Agricultural and Life Sciences,

The University of Tokyo

1-1-1, Yayoi, Bunkyo-ku, Tokyo 113-8657

※2 Research Institute for Sustainable Chemistry,

National Institute of Advanced Industrial Science and Technology

3-11-32, Kagamiyama, Higashi-hiroshima, Hiroshima 739-0046

※3 Tottori University of Environmental Studies 1-1-1, Wakabadai-kita, Tottori-city, Tottori 689-1111

$\dagger \quad$ Corresponding author: PXL05260@nifty.ne.jp several studies have examined methods in reducing the cost of enzymatic hydrolysis, such as improvement of productivity of enzymes, production of enzymes with high activity, optimum combination of several different enzymes. One of the most effective ways is to reuse enzymes. There are two approaches that have been studied; one is to recover enzymes in the liquid phase and the other is to reuse enzymes in the hydrolysis residue ${ }^{1) \sim 12}$. Ramos et al. ${ }^{3)}$ reported that reusing enzymes only from the filtrate after the removal of unhydrolyzed residues was insufficient and that adding the unhydrolyzed residue improved the hydrolysis yield at the recycle round. Gregg and Saddler ${ }^{5)}$ reported that most of the added cellulase was adsorbed on the residual substrate after most of cellulosic substrate has been hydrolyzed. Nonaka et al. ${ }^{10)}$ reported cellulase bound to lignin is working as immobilized cellulase. These 
results indicate that recovery of enzymes from the solid residue is necessary for efficient enzyme recycling, and thus it is important to evaluate the activity of the enzymes remaining in the solid residue of enzymatic hydrolysis.

Enzyme activity in the liquid phase such as filter paper unit (FPU), activity on carboxymethylcellulose (CMCase), and $\beta$-glucosidase activity, has been evaluated by several studies ${ }^{1) \sim 6)}{ }^{13)}$. Protein in the liquid phase has also been measured in other reports ${ }^{1)} \sim$ 6) 13). In the solid residue, however, enzymes are adsorbed onto the substrate and are difficult to completely isolate, thus it is not easy to estimate the activity using the same method as that for the liquid phase. The difference between initial enzyme activity and enzyme activity in the liquid phase is not necessarily the enzyme activity remaining in the solid residue due to deactivation of enzyme or irreversible adsorption on lignin and other residual substrates. Lee et al. hydrolyzed a mixture of fresh substrate and hydrolysis residue and evaluated the recovered cellulase activity ${ }^{3)}$; however, this method cannot be easily used for hydrolysis residues at high substrate concentrations because their method needs the whole hydrolysis residues to evaluate the recovered cellulase activity. In this study we proposed a method for evaluating the reusable cellulase activity in the residue of enzymatic hydrolysis and measured the cellulase activity by the method. Then we carried out two other hydrolysis experiments in order to examine the reusable cellulase activity measured by the proposed method. In the end repeated enzymatic hydrolysis at high substrate concentration with reuse of enzyme remaining in the solid residue of enzymatic hydrolysis was performed to examine the application of our proposed method for practical reuse of enzymes remaining in solid residue of enzymatic hydrolysis.

\section{Materials and methods}

\subsection{Substrate}

Oxygen delignified kraft pulp (OKP) produced from soft wood was used for the preparation of the hydrolysis residue. Never-dried OKP was kindly supplied by Oji Paper Co., Ltd., Japan. The pulp was stored at $4{ }^{\circ} \mathrm{C}$ in a refrigerator and washed with pure water three times before hydrolysis. Gerber et al. reported that fiber history has a large influence on enzyme adsorption and that cellobiohydrolase I (CBH I) adsorption onto never-dried fiber was two to three times higher than that onto once-dried fiber ${ }^{14)}$. The pulp sample was thus kept wet. The water content was measured using a Moisute Analyzer MX-50 (A\&D Co., Ltd., Tokyo, Japan). The composition was determined to be $78.0 \%$ glucan, $10.7 \%$ xylan and $2.3 \%$ acid insoluble lignin, according to the analytical procedure recommended by the National
Renewable Energy Laboratory ${ }^{15}$. Mannan content was not measured because the peaks of mannose and the other components in the kraft pulp product overlapped with each other in the HPLC spectrum. Microcrystalline Cellulose, Avicel PH101 (Fluka, Switzerland) was used as substrate for evaluating the cellulase activity in the OKP hydrolyzed residue.

\subsection{Preparation of OKP hydrolyzed residues for evaluation of cellulase activity}

The hydrolysis of OKP was performed in $50 \mathrm{mM}$ acetate buffer $(\mathrm{pH}=5.0)$ supplemented with 12.5 FPU/ g-glucan of Acremonium cellulase (Meiji Seika Co., Japan). The concentration of the substrate was 40 g-glucan/ $\mathrm{L}$ and the total liquid volume was $40 \mathrm{~mL}$. The reaction temperature was set at $45^{\circ} \mathrm{C}$. OKP hydrolyzed residues at different hydrolysis rate were prepared by stopping the hydrolysis at different time points. The solid residue and hydrolysate were separated by centrifugation and was chilled in refrigerator. The residues were washed with 50 $\mathrm{mM}$ acetate buffer ( $\mathrm{pH}$ 5.0) three times to remove the sugar components in the solid residue. After washing, the wet weight of the solid residue was measured so that drying should not damage enzymes in the residue. To determine the amount of solubilized glucan, the hydrolysate was hydrolyzed with $4 \% \mathrm{H}_{2} \mathrm{SO}_{4}$ at $121^{\circ} \mathrm{C}$ for $1 \mathrm{~h}$ and the glucose concentration was measured. Glucan hydrolysis rate was defined as the raito of glucan solublized during enzymatic hydrolysis to initial glucan.

\subsection{Evaluation of cellulase activity remaining in the OKP hydrolyzed residues using Avicel}

Hydrolysis of Avicel using the prepared OKP hydrolyzed residues instead of enzymes was carried out to evaluate cellulase activity remaining in the residues. Approximately $0.1 \mathrm{~g}$ of the wet OKP hydrolyzed residue was suspended in $50 \mathrm{mM}$ acetate buffer solution, $20 \mathrm{~mL}$ in volume and with a pH level of 5 , containing $20 \mu \mathrm{L}$ of Novozyme 188 (Novozymes, Denmark). Novozyme 188 was supplemented to avoid cellobiose inhibition. One gram of Avicel was added to the suspension and the reaction mixture was incubated at $45^{\circ} \mathrm{C}$ for $48 \mathrm{~h}$. The suspension without Avicel was also incubated at $45^{\circ} \mathrm{C}$ for $48 \mathrm{~h}$ to determine the glucose released from each solid residue. The glucose production rate between $24 \mathrm{~h}$ and $48 \mathrm{~h}$ was used to evaluate the cellulase activity. The experiments were performed in triplicate.

Cellulase activity in the $0.1 \mathrm{~g}$ of the OKP hydrolyzed residues was evaluated by the standard curve of cellulase loading versus glucose production rate between $24 \mathrm{~h}$ and 
48 h. The standard curve was obtained by the hydrolysis of $1 \mathrm{~g}$ of Avicel in $20 \mathrm{~mL}$ of $50 \mathrm{mM}$ acetate buffer ( $\mathrm{pH}$ 5.0) using different amounts of cellulase (0, 0.1, 0.2, 0.4, 0.8 FPU). The hydrolysis was also performed at $45^{\circ} \mathrm{C}$ for $48 \mathrm{~h}$, supplemented with $20 \mu \mathrm{L}$ of Novozyme 188 .

Cellulase activity remaining in the OKP hydrolyzed residue was evaluated as follows. Cellulase activity in 0.1 $\mathrm{g}$ of the solid residue was estimated using the standard curve and then total cellulase activity in the solid residue was calculated. The total cellulase activity was defined as reusable cellulase activity. The recovery rate was defined as the ratio of reusable cellulase activity remaining in the solid residue to initial cellulase activity.

\subsection{Hydrolysis with cellulase remaining in the OKP hydrolyzed residue \\ Cellulase activity in the OKP hydrolyzed residue} was also evaluated by the modified method based on that of Lee et al. The residues was prepared in the same condition as described in subsection 2.2. The concentration of the substrate was 40 g-glucan/L and the total liquid volume was $60 \mathrm{~mL}$. The reaction time was set $18 \mathrm{~h}$ and $24 \mathrm{~h}$. The whole prepared residue after washing and fresh OKP substrate that contained the same amount of glucan as hydrolyzed in the preparation of the solid residue were mixed in $50 \mathrm{mM}$ acetate buffer at the final glucan concentration of $40 \mathrm{~g} / \mathrm{L}$ and the total liquid volume of $60 \mathrm{~mL}$. The mixture was supplemented with $20 \mu \mathrm{L}$ of Novozyme 188 per gram of glucan and incubated at $45^{\circ} \mathrm{C}$ for 48 h. Novozyme 188 was supplemented to avoid cellobiose inhibition. The amount of fresh pulp substrate was determined by the amount of glucan as hydrolyzed during preparation of hydrolysis residue.

For estimation of cellulase activity, hydrolysis using the same concentration was performed with different cellulase loadings (0, 2.5, 5, 7.5 10, and $12.5 \mathrm{FPU} / \mathrm{g}$-glucan).

\subsection{Evaluation of possibility of cellulase reuse from OKP hydrolyzed residue}

Another hydrolysis experiment was carried out in order to evaluate the possibility of cellulase reuse from solid residue after hydrolysis. Hydrolysis residue was prepared using the same conditions as described in subsection 2.2. The concentration of the substrate was $40 \mathrm{~g}$-glucan/L and the total liquid volume was $60 \mathrm{~mL}$. The reaction time was set $24 \mathrm{~h}$. The hydrolysis for preparation of the residue was defined as the first round. The second round of hydrolysis was performed as follows. Fresh pulp substrate that contained the same amount of glucan as hydrolyzed in the first round of hydrolysis, fresh cellulase that had the same activity as lost in the first round and the whole prepared residue after washing were mixed in $50 \mathrm{mM}$ acetate buffer at a final glucan concentration of $40 \mathrm{~g} / \mathrm{L}$ and the total liquid volume of $60 \mathrm{~mL}$. The reaction mixture was incubated at $45^{\circ} \mathrm{C}$ for $24 \mathrm{~h}$. The cellulase activity lost in the first round of hydrolysis was calculated from the result of the evaluation of the cellulase activity in the residue as previously described. After enzymatic hydrolysis, the hydrolysate was hydrolyzed with $4 \% \mathrm{H}_{2} \mathrm{SO}_{4}$ at $121^{\circ} \mathrm{C}$ for $1 \mathrm{~h}$ and the glucose concentration was measured.

\subsection{Repeated enzymatic hydrolysis at high substrate concentration with reuse of enzyme remaining in the solid residue of enzymatic hydrolysis}

Repeated enzymatic hydrolysis at high substrate concentration with reuse of enzyme remaining in the solid residue of enzymatic hydrolysis was performed to examine the application of our proposed method for practical reuse of enzymes remaining in solid residue of enzymatic hydrolysis. Fig. 1 showed flow of the repeated enzymatic hydrolysis with reuse of enzyme remaining in the solid residue of enzymatic hydrolysis. The first round enzymatic hydrolysis was performed at a substrate concentration of $200 \mathrm{~g} /$ $\mathrm{L}$ and a total liquid volume of $80 \mathrm{~mL}$ using an enzyme cocktail containing $10 \mathrm{FPU}$ of Acremonium cellulase and $0.01 \mathrm{~g}$ of Cellulosin GM5 (HBI Enzyme Inc., Japan) per gram of dry substrate. Cellulosin GM5 was supplemented for sufficient hydrolysis of mannan. The stated amount of OKP and the enzyme cocktail were mixed in $50 \mathrm{mM}$ sodium acetate buffer ( $\mathrm{pH} 5.0$ ), total liquid volume $80 \mathrm{~mL}$. The reaction mixtures were incubated at $45^{\circ} \mathrm{C}$. After first round hydrolysis for $96 \mathrm{~h}$, the solid residue and hydrolysate were separated by centrifugation and the hydrolysate was hydrolyzed with $4 \% \mathrm{H}_{2} \mathrm{SO}_{4}$ at $121{ }^{\circ} \mathrm{C}$ for 1 hour. Then the glucose concentration of the hydrolysate after acid hydrolysis was measured and glucan hydrolysis rate was calculated. Centrifugal washing was not carried out in this experiment.

Each recycle round of hydrolysis was performed as follows. OKP and enzyme cocktail was mixed in $50 \mathrm{mM}$ acetate buffer solution, $80 \mathrm{~mL}$ in volume and $\mathrm{pH}$. The whole solid residue separated by centrifugation was added to the mixture and the reaction mixture was incubated for $96 \mathrm{~h}$ at $45^{\circ} \mathrm{C}$. The amount of OKP $\left(\mathrm{OKP}_{\text {add }}\right)$, Acremonium cellulase $\left(\mathrm{C}_{\text {add }}\right)$ and cellulosin GM5 $\left(\mathrm{H}_{\text {add }}\right)$ added in each recycle round were calculated by equation (1-3). Recovery rate of cellulase activity from solid residue at a substrate concentration of $200 \mathrm{~g} / \mathrm{L}$ (around $160 \mathrm{~g}$-glucan/L) was assumed to be the same as that at a substrate concentration 


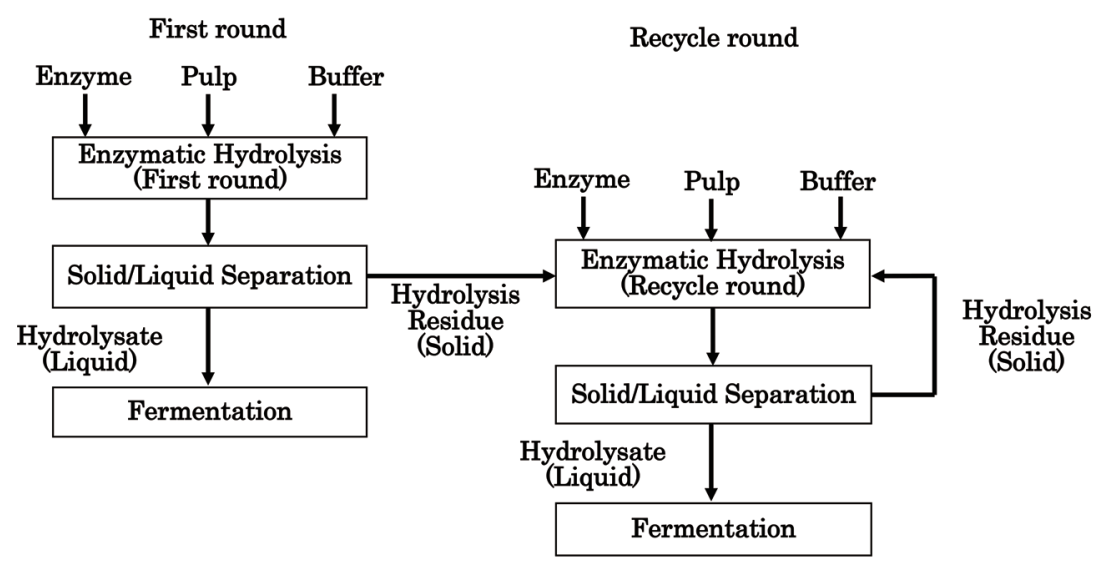

Fig. 1 Flow of repeated enzymatic hydrolysis at high substrate concentration with reuse of enzyme remained in the solid residue after hydrolysis

of 40 g-glucan/L. Recovery rate of cellulosin GM5 was assumed to be the same as that of cellulase activity.

$\mathrm{OKP}_{\text {add }}(\mathrm{g})$

$=16.0(\mathrm{~g}) \times$ glucan hydrolysis rate in the first round $(1)$

$\mathrm{C}_{\text {add }}(\mathrm{FPU})=160(\mathrm{FPU}) \times(100$ - recovery rate $) / 100$

$\mathrm{H}_{\text {add }}(\mathrm{mg})=160(\mathrm{mg}) \times(100-$ recovery rate $) / 100$

Note that the amount of OKP, cellulose, and cellulosin GM5 used in the first round of hydrolysis were 16.0, 160, and $160 \mathrm{~g}$, respectively. After each recycle round of hydrolysis for $96 \mathrm{~h}$, the solid residue and hydrolysate were also separated by centrifugation and the hydrolysate was hydrolyzed with $4 \% \mathrm{H}_{2} \mathrm{SO}_{4}$ at $121^{\circ} \mathrm{C}$ for 1 hour. Then the glucose concentration of the hydrolysate after acid hydrolysis was measured.

\subsection{Sugar analysis}

Glucose concentration in hydrolysate was measured by the mutarotase-GOD method using a Glucose CIItest kit (Wako Pure Chemical Industries, Ltd., Japan). The composition of OKP, glucose, xylose, and mannose were determined using a high-performance liquid chromatography system (Jasco Co., Tokyo, Japan) equipped with a refractive index detector (RI-2031 Plus, Jasco Co.), an Aminex HPX$87 \mathrm{P}$ column $(7.8 \mathrm{~mm}$ ID $\times 30 \mathrm{~cm}$, Bio Rad, Hercules, USA), and a Carbo-P micro-guard cartridge (Bio Rad, Hercules, USA). The column oven was set at $80^{\circ} \mathrm{C}$. Samples were eluted at $1 \mathrm{~mL} / \mathrm{min}$ with water. Glucose, xylose and mannose in the hydrolysate of repeated hydrolysis were also analyzed using this HPLC system.

\section{Results and Discussion}

3.1 Preparation of OKP hydrolyzed residues for evaluation of cellulase activity

Five OKP hydrolyzed residues were prepared by stopping the hydrolysis reaction at different time points.
The wet weight of the solid residue was measured in case drying should damage enzymes in the residue. Thus each residue had a different water content. The glucan hydrolysis rate and the wet weight of these five residues are presented in Table 1.

\subsection{Evaluation of reusable cellulase activity remaining in the OKP hydrolyzed residues}

Glucose concentration of the hydrolysis of $0.1 \mathrm{~g}$ OKP hydrolyzed residue without Avicel was almost stable in each sample after $24 \mathrm{~h}$, indicating that glucose produced after $24 \mathrm{~h}$ was derived exclusively from the cellulose in Avicel. Thus, the glucose production rate with Avicel between 24 and $48 \mathrm{~h}$ was used to evaluate the cellulase activity.

The standard curve of cellulase loading versus glucose production rate between 24 and $48 \mathrm{~h}$ is shown in Fig. 2 and expressed by Equation (1). Cellulase activity in 0.1 $\mathrm{g}$ of the OKP hydrolyzed residue was estimated using the standard curve and then cellulase activity in the total OKP hydrolyzed residue was calculated.

Table 1 Evaluation of cellulase activity remaining in OKP hydrolyzed residues. Recovery rate is defined as the ratio of cellulase activity remaining in OKP hydrolyzed residues to the initial cellulase activity using in hydrolysis of the OKP

\begin{tabular}{cccc}
\hline $\begin{array}{c}\text { Hydrolysis time } \\
(\mathrm{h})\end{array}$ & $\begin{array}{c}\text { Glucan } \\
\text { hydrolysis rate* } \\
(\%)\end{array}$ & $\begin{array}{c}\text { Weight** } \\
(\mathrm{g})\end{array}$ & $\begin{array}{c}\text { Recovery rate } \\
(\%)\end{array}$ \\
\hline 12 & 53 & 8.70 & 90 \\
\hline 18 & 75 & 6.87 & 69 \\
\hline 24 & 84 & 5.06 & 56 \\
\hline 30 & 90 & 3.86 & 53 \\
\hline 48 & 99 & 1.77 & 23 \\
\hline
\end{tabular}

${ }^{*}$ Raito of glucan solubilized during enzymatic hydrolysis to initial glucan

${ }^{* *}$ Wet weight 


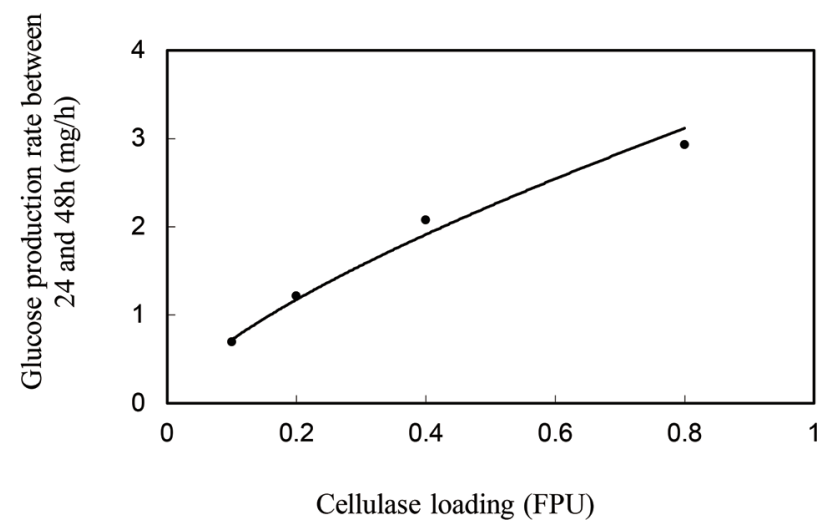

Fig. 2 Standard curve of cellulase loading versus glucose production rate between 24 and 48 h of enzymatic hydrolysis of Avicel. The hydrolysis of Avicel was performed at a concentration of $50 \mathrm{~g} / \mathrm{L}$, cellulase loading of $0.1,0.2$, 0.4 and $0.8 \mathrm{FPU}$, temperature $45^{\circ} \mathrm{C}$ and $\mathrm{pH}$ of 5.0

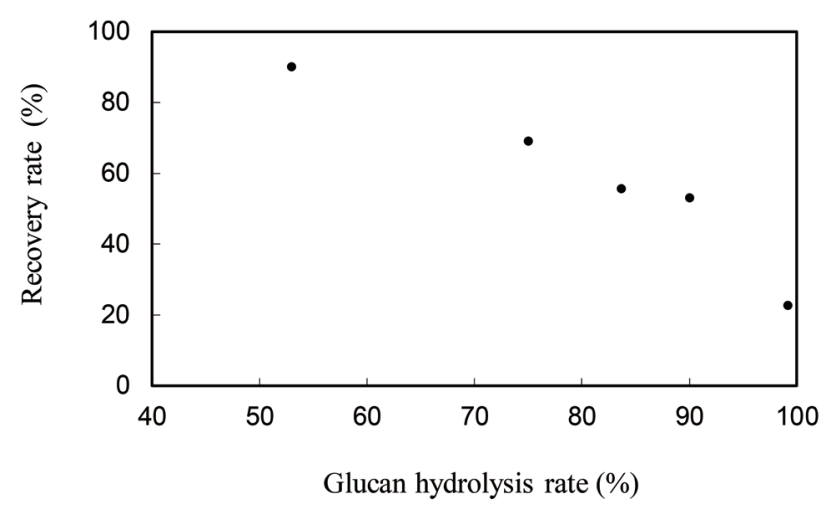

Fig. 3 Evaluation of cellulase activity remaining in OKP hydrolyzed residues. Recovery rate is defined as the ratio of cellulase activity remaining in OKP hydrolyzed residues to the initial cellulase activity using in hydrolysis of the OKP

$$
y=3.64 x^{0.704}
$$

$y$ : Glucose production rate between 24 and $48 \mathrm{~h}(\mathrm{mg} / \mathrm{h})$

$x$ : Cellulase loading (FPU)

The results of evaluating the reusable cellulase activity in the solid residue are shown in Fig. 3. The recovery rate was defined as the ratio of the cellulase activity in the total OKP hydrolyzed residue to initial cellulase activity. Approximately 70\% of cellulase activity remained in the solid residue after $70 \%$ of the glucan was hydrolyzed. Lee et al. reported that $61 \%$ activity remained in the residue after $76 \%$ of the cellulose was hydrolyzed ${ }^{3)}$. They used alkaline- and peroxide-treated birch that contained 90\% cellulose and 4\% lignin. Although the composition was slightly different from what we used in our study and the enzymatic hydrolysis was performed at a substrate concentration of $2 \%$ and at a cellulase loading of 20FPU/g-cellulose, their result was similar to our findings.

After $99 \%$ of the glucan was hydrolyzed, $22 \%$ of the cellulase activity still remained in the solid residue. Gregg and Saddler reported that cellulases adsorbed onto residual lignin are still active and capable of cellulose hydrolysis ${ }^{5}$. Nonaka et al. reported cellulase bound to lignin maintains enzymatic activity and is working as immobilized cellulase ${ }^{10)}$. According to their findings, the enzymes adsorbed on lignin maintained their enzymatic activities. Thus some of the enzymes adsorbed on lignin worked as immobilized cellulase and hydrolyzed cellulose substrates.

\subsection{Hydrolysis with cellulase remaining in the OKP hydrolyzed residue}

The glucan hydrolysis rate after $18 \mathrm{~h}$ and $24 \mathrm{~h}$ of hydrolysis was $66 \%$ and $72 \%$, respectively. Fig. 4 shows the result of hydrolysis with cellulase in the OKP hydrolyzed residue. The time course of the hydrolysis using the 18-h hydrolysis residue is located between the curves of 7.5 FPU/ g-glucan and $10 \mathrm{FPU} / \mathrm{g}$-glucan. Therefore, the reusable cellulase activity was estimated to be about $70 \%$ of the initial cellulase activity of $12.5 \mathrm{FPU} / \mathrm{g}$-glucan. The time course of the hydrolysis using the 24-h hydrolysis residue is located slightly below that of the 18-h hydrolysis residue and the reusable cellulose activity was estimated to be about $65 \%$ of the initial cellulose activity. These results are a little

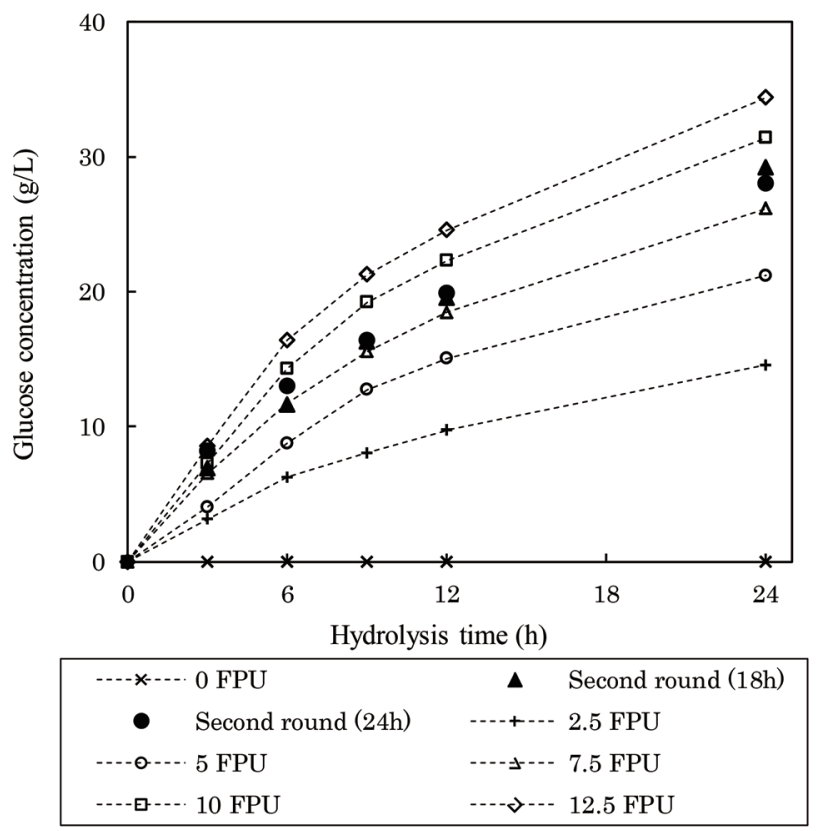

Fig. 4 Time course of glucose concentration of hydrolysis with cellulase in two OKP hydrolyzed residues and hydrolysis with fresh cellulase at different cellulase loadings $(0,2.5,5$, 7.5, 10, $12.5 \mathrm{FPU} / \mathrm{g}$-glucan). Hydrolysis was performed at a glucan concentration of $40 \mathrm{~g} / \mathrm{L}$ at $45^{\circ} \mathrm{C}$. The hydrolysis residues were prepared in the following hydrolysis condition, $40 \mathrm{~g} / \mathrm{L}$ glucan concentration, $12.5 \mathrm{FPU} /$ g-glucan cellulase loading, reaction temperature of $45^{\circ} \mathrm{C}$ 
lower than those shown in Fig. 3. Although the cellulose content of each hydrolysis was the same, the lignin content of the hydrolysis using the 18-h or 24-h hydrolysis residue was higher than that of the hydrolysis using fresh OKP and cellulase. Thus, more cellulase was adsorbed on lignin in the hydrolysis using the 18-h or 24-h hydrolysis residue. As a result, the glucan hydrolysis rate of the hydrolysis using the 18-h or 24-h hydrolysis residue was lower than that of the hydrolysis using fresh OKP and cellulose.

\subsection{Evaluation of possibility of cellulase reuse from OKP hydrolyzed residue}

Three two-round hydrolysis tests were carried out to evaluate possibility of cellulase reuse from solid hydrolysis residue. The results are shown in Table 2. Based on the results of our evaluation of cellulase activity remaining in the OKP hydrolyzed residue in this study (Fig. 3), the amount of fresh cellulase supplemented in the second round was 9.6 FPU of that of cellulase $32 \%$ of initial cellulase, 30 FPU) for Residues 1 and 2, and 10.5 FPU (35\% of initial cellulase) for Residue 3. As shown in Table 2 , by supplementing fresh cellulase estimated by the result of evaluation of reusable cellulase activity in the solid residue, the glucan hydrolysis rate in the second round was almost the same as that using fresh cellulase (in the first round of hydrolysis). This showed that cellulase reuse was successfully achieved as estimated by the recovery rate evaluated in this study (Fig. 3). Thus our proposed method to evaluate cellulase activity in solid residue after enzymatic hydrolysis is efficient for cellulase reuse from solid hydrolysis residue.

\subsection{Repeated enzymatic hydrolysis at high substrate} concentration with reuse of enzyme remained in the solid residue after hydrolysis

The glucan hydrolysis rate of the first round of hydrolysis for $96 \mathrm{~h}$ was $70 \%$. The amount of OKP (OKP add), Acremonium cellulase $\left(\mathrm{C}_{\text {add }}\right)$ and cellulosin $\mathrm{GM} 5\left(\mathrm{H}_{\text {add }}\right)$ added in each recycle round were determined to be $11.2 \mathrm{~g}$, $48 \mathrm{FPU}$ and $48 \mathrm{mg}$, respectively. As shown in Fig. 5, the glucose concentration showed no significant differences

Table 2 Glucan conversion rate of hydrolysis with fresh cellulase (First round hydrolysis) and hydrolysis with fresh cellulase and cellulase reusing from solid residue of the first round hydrolysis

\begin{tabular}{cccc}
\hline & Residue 1 & Residue 2 & Residue 3 \\
\hline Glucan conversion rate (\%) & & & \\
First round* & 74 & 74 & 77 \\
Second round $^{* *}$ & 72 & 77 & 78 \\
\hline
\end{tabular}

${ }^{*}$ Hydrolysis with fresh cellulase

** Hydrolysis with the cellulase in the hydrolysis residue supplemented with 9.6 FPU of cellulase (32\% of initial cellulase) for Residues 1 and 2, 10.5 FPU (35\% of initial cellulase) for Residue 3

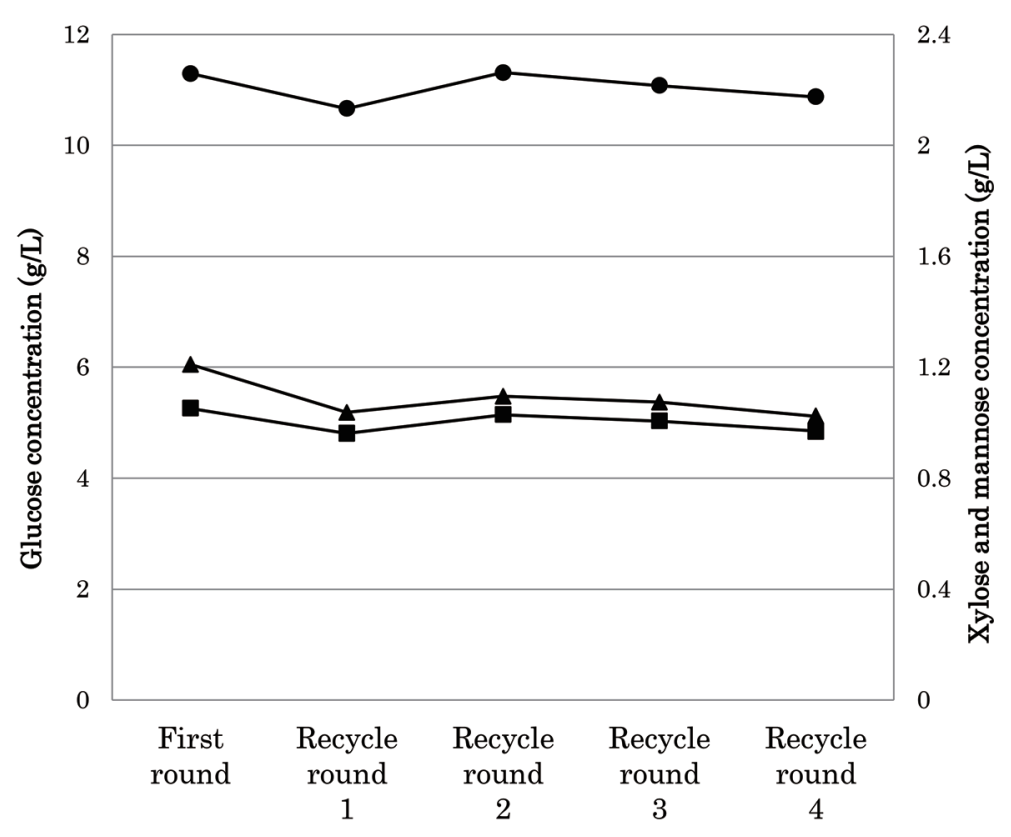

Fig. 5 Sugar concentrations of repeated enzymatic hydrolysis at high substrate concentration with reuse of enzyme remained in the solid residue after hydrolysis. The first round enzymatic hydrolysis was performed at a substrate concentration of $200 \mathrm{~g} / \mathrm{L}$ at $45^{\circ} \mathrm{C}$ for $96 \mathrm{~h}$ using an enzyme cocktail containing $10 \mathrm{FPU}$ of Acremonium cellulase and $10 \mathrm{mg}$ of Cellulosin GM5 per gram of dry substrate, total liquid volume $80 \mathrm{~mL}$. The amount of OKP substrate, Acremonium cellulase and cellulosin GM5 added in each recycle round were 11.2 g, 48 FPU and 48 mg, respectively. Symbols: circles, glucose concentration; triangles, xylose concentration; squares, mannose concentration 
among each round, indicating that enzymes related with cellulose hydrolysis were recovered from the solid residue after hydrolysis at a high substrate concentration as we estimated from the recovery rate measured by our proposed method. The mannose concentration also showed no significant differences among each round. Recovery rate of enzymes related with mannan hydrolysis was similar to that of enzymes related with cellulose hydrolysis. On the other hand, xylose concentration was slightly lower in the recycle rounds than that in the first round. Recovery rate of enzymes enzymes related with xylan hydrolysis was lower than that of enzymes related with cellulose hydrolysis. In addition, the glucan hydrolysis rate of OKP was over $90 \%$ in total because unhydrolyzed cellulose remaining in the solid residue was also recycled and hydrolyzed in the recycle round. Cellulase consumption was 7.5 FPU/g-glucose, which was about half of that without recycling (16.4 FPU/ g-glucose). The repeated enzymatic hydrolysis with reuse of enzyme remained in the solid residue after hydrolysis was effective both for enzyme recycle and for improvement of glucan hydrolysis rate. For more effective reuse of enzymes, it is necessary to evaluate other activities, such as $\beta$-glucosidase activity, CMCase, and hemicellulase activity.

\section{Conclusion}

In this study, we proposed a method for evaluating the reusable cellulase activity remaining in the residue of enzymatic hydrolysis. Approximately $70 \%$ of cellulase activity remained in the solid residue after $70 \%$ of the glucan was hydrolyzed and $22 \%$ of cellulase activity still remained in the solid residue after 99\% of the glucan was hydrolyzed. The result agreed well with the findings of Lee et al. ${ }^{4)}$ and Gregg and Saddler ${ }^{5)}$. Cellulase reuse from hydrolysis residue was successfully achieved as estimated by the recovery rate of cellulase activity remaining in hydrolysis residue evaluated in this study. In order to examine the application of our proposed method for practical reuse of enzymes remaining in solid residue of enzymatic hydrolysis we carried out the other hydrolysis experiment: repeated enzymatic hydrolysis at high substrate concentration with reuse of enzyme remaining in the solid residue after hydrolysis. The glucose concentration in each recycle round of hydrolysis was almost the same as that in the first round of hydrolysis using fresh enzymes, indicating that enzymes were recovered from the solid residue of enzymatic hydrolysis as we estimated from the recovery rate measured by our proposed method. Thus our proposed method is efficient for evaluating cellulase activity in solid residue after enzymatic hydrolysis.

\section{References}

1) Tanaka, M.; Fukui, M.; Matsuno, R., Biotechnol. Bioeng., 32, 897-902 (1998)

2) Hogan, C. M.; Mes-Hartree, M., J. Ind. Microbiol., 6, 253262 (1990)

3) Ramos, L. P.; Breuil, C.; Saddler, J. N., Enzyme Microb. Technol., 15, 19-25 (1993)

4) Lee, D.; Yu, A. H. C.; Saddler, J. N., Biotechnol. Bioeng., 45, 328-336 (1995)

5) Gregg, D. J.; Saddler, J. N., Biotechnol. Bioeng., 51, 375383 (1996)

6) Lu, Y.; Yang, B.; Gregg, D.; Saddler, J. N.; Mansfield, S. D., Appl. Biochem. Biotechnol., 98-100, 641-654 (2002)

7) Knutsen, J. S.; David, R. H., Appl. Biochem. Biotechnol., 98-100, 1161-1172 (2002)

8) Knutsen, J. S.; David, R. H., Appl. Biochem. Biotechnol., 113-116, 585-599 (2004)

9) Steele, B.; Raj, S.; Nghiem, J.; Stowers, M., Appl. Biochem. Biotechnol., 121-124, 901-910 (2005)

10) Nonaka, H.; Tanaka, H.; Funaoka, M., J. Jpn. Inst. Energy, 90(10), 977-981 (2011)

11) Kobayashi, A.; Nonaka, H.; Funaoka, M., J. Jpn. Inst. Energy, 91(10), 992-997 (2012)

12) Kobayashi, A.; Nonaka, H.; Funaoka, M., J. Jpn. Inst. Energy, 92(10), 930-935 (2013)

13) Ishihara, M.; Uemura, S.; Hayashi, N.; Jellison, J.; Shimizu, K., J. Ferment. Bioeng., 72, 96-100 (1991)

14) Gerber, P. J.; Joyce, T. W., Heitmann, J. A.; Siika-aho, M.; Buchert, J., Cellul., 4, 255-268 (1997)

15) Sluiter, A.; Hames, B.; Ruiz, R.; Scarlata, C.; Sluiter, J.; Templeton, D.; Crocker, D., Determination of structural carbohydrates and lignin in biomass, Laboratory Analytical Procedure (LAP), NREL, U.S.A. 2008; TP510-42618 